\title{
特集記事
}

\section{近赤外吸収イメージング法を利用した マイクロ流路内水溶液の反応拡散現象の可視化*}

\author{
川嶋 大介**，角田 直人***

\section{Visualization of Reaction-diffusion Phenomena of Aqueous Solutions in Microfluidic Channels Using Near-infrared Absorption Imaging Technique}

\author{
Daisuke Kawashima and Naoto Kakuta
}

\section{1. 緒 論}

マイクロ流体チップを利用した微量試料の分析，化学 合成, 分離に関する研究が盛んに行われているが1,2), 流路構造の設計, 流体の最適制御, 反応・分離の評価に は物質濃度と温度の計測が欠かせない。例えば, microPCR (Polymerase Chain Reaction)では区画ごとの温度 制御による反応プロセスの最適化が求められる1).これ まで様々な計測法が研究されてきたが, 蛍光プローブを 用いた手法 ${ }^{3)}$ に加えて, 近年ではラマン分光法 ${ }^{4}$ やイン ピーダンス分光法 ${ }^{5)}$ といったプローブ物質を必要としな い技術も開発されている，一方，著者らは近赤外分光法 を応用した濃度と温度のイメージングに取り組んでき た $^{6-8)}$. 近赤外分光法は多くの分野ですでに広く用いら れている分析法であるが, 最近は, hyperspectral imaging と呼ばれる分光画像計測法 ${ }^{9)}$ の進展に伴い, 新 たな学術および応用分野を開拓しつつある．著者らのイ メージング法の特徴は, 溶質濃度と温度に対する水の近 赤外吸収バンドのスペクトル変化を巧みに利用する点に あり, 従来の手法や hyperspectral imaging に比べてイ メージング速度に優れ，装置も簡略化しやすい．また, マイクロ流体チップの材料であるガラスや polydimethylsiloxane (PDMS) は近赤外光を透過するた め, 既製のマイクロ流体チップをそのまま使用できるこ とも実用上の利点である.

本稿では, 近赤外吸収イメージング法の原理と計測シ ステムを解説し, 代表的なアルコール, 酸, アルカリ, 塩の水溶液に関する温度と濃度の可視化結果を紹介する. 分光イメージングデバイスには波長可変の音響光学式 フィルタや液晶型フィルタ, 回折格子式のライン走査デ バイスなどがあるが，ここでは高速撮像およびコストの

* 原稿受付 2019 年 3 月 15 日

** 正会員 千葉大学 大学院工学研究院

（率 263-8522 千葉県千葉市稲毛区弥生町 1-33,

E-mail :dkawa@chiba-u.jp)

*** 正会員 首都大学東京 大学院システムデザイン研究科
点から光学バンドパスフィルタを用いた装置を紹介する.

\section{2. 近赤外吸収イメージング法}

\section{1 測定原理}

本節では，近赤外域における水の吸収スペクトルの特 徵について概説する。近赤外域は一般に波長 $\lambda=800$ $\mathrm{nm}$ から $\lambda=2500 \mathrm{~nm}$ までを指し, 水の吸収バンドが複 数存在する.Fig. 1 (a) は $\lambda=1350-2150 \mathrm{~nm} に$ における 水の吸収スペクトルであるが ${ }^{10)}$ ，およそ $\lambda=1450 \mathrm{~nm}$, $1940 \mathrm{~nm}$ をピークとする 2 つ吸収バンドが観察される. ここで, 縦軸の吸光度 $A$ は入射光強度 $I_{0}$ と透過光強度 $I$ を用いて次式で定義される（自然対数によって定義さ れるケースもあるが，ここでは常用対数を採用する).

$$
A=-\log _{10}\left[I(\lambda) / I_{0}(\lambda)\right]
$$

吸収バンドは水分子の振動モードに対応しており， $\lambda=$ $1450 \mathrm{~nm}$ の吸収バンドは対称伸縮振動 $\left(\nu_{1}\right)$ と逆対称伸 縮振動 $\left(\nu_{3}\right)$ の結合音 $\left(\nu_{1}+\nu_{3}\right), \lambda=1940 \mathrm{~nm}$ は変角振 動 $\left(\nu_{2}\right)$ と $\nu_{3}$ の結合音 $\left(\nu_{2}+\nu_{3}\right)$ である ${ }^{11,12)}$. 2 つの大 きさは異なるため, マイクロ流路深さすなわち試料光路 長 $d$ に応じて使用する吸収バンドを選択する必要があ る。大まかに言えば, 水や希薄水溶液の場合, $\nu_{1}+\nu_{3}$ バ ンドは $d=0.1-1.0 \mathrm{~mm}, \nu_{2}+\nu_{3}$ バンドは $d=0.01-0.1$ $\mathrm{mm}$ での使用が適当である ${ }^{11)}$.

Fig. 1 (a) は吸収バンドのスペクトルが温度 $T$ に従っ て変化することも示している，温度上昇に従い，両バン ドとも短波長側にシフトする。これは水分子間の水素結 合状態に起因し, 温度上昇により分子振動が活発になり, 水素結合状態の水分子より自由水の側に平衡が移動する と解釈されている ${ }^{12)}$. 同図には， $\lambda=1850-2000 \mathrm{~nm}$ の 吸光度差 $\Delta A$ も示した。ここで, $\Delta A$ は

$$
\Delta A(\lambda)=A(\lambda)-A_{\text {ref }}(\lambda)=-\log _{10}\left[I(\lambda) / I_{\text {ref }}(\lambda)\right]
$$

で定義され，基準透過光強度 $I_{r e f}$ には温度 $16^{\circ} \mathrm{C}$ のを用 いた. $\Delta A$ は $\lambda=1905 \mathrm{~nm}$ で極大值を示し, $1935 \mathrm{~nm}$ で 変化のない等吸収点が存在する。次に 1 成分水溶液の一 例としてエタノール水溶液の濃度ごとの $A(\lambda)$ を Fig. 1 (b)に示す. エタノール濃度の増加とともに, 吸収バン 
(a)

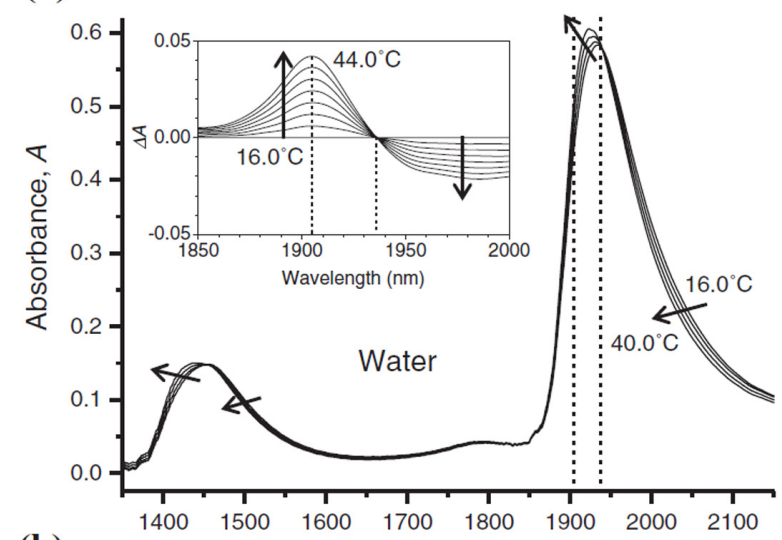

(b)

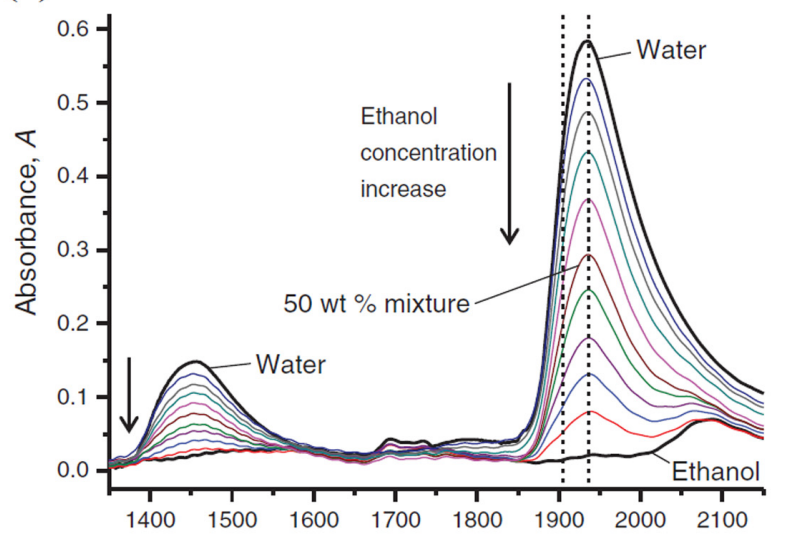

Fig. 1 (a) Absorption spectra of water at 16.0, 24.0, 32.0 and $40.0{ }^{\circ} \mathrm{C}$ The arrows indicate the direction of temperature increase. The inset shows the absorbance difference spectra of water from $16.0{ }^{\circ} \mathrm{C}$ to $44.0{ }^{\circ} \mathrm{C}$ with a step of $4.0{ }^{\circ} \mathrm{C}$, where the reference temperature is $16.0{ }^{\circ} \mathrm{C}$. The optical path length is $0.1 \mathrm{~mm}$. The vertical dotted lines indicate the wavelengths of $1905 \mathrm{~nm}$ and $1935 \mathrm{~nm}$. (b) Absorption spectra of ethanol?water mixtures with varying the ethanol mass fraction from $0 \mathrm{wt} \%$ to 100 wt\% with a step of $10 \mathrm{wt} \%$ at $16.0{ }^{\circ} \mathrm{C}$. Reproduced from Ref. 10.

ドにおける $A$ が単調に減少することが分かる. 水溶液 の場合, $A$ は水と溶質の吸収分の和として, 次のよう に表すことができる。

$$
\begin{gathered}
A\left(\lambda, T, c_{\mathrm{e}}\right)=\mu\left(\lambda, T, c_{\mathrm{e}}\right) d \log _{10} e \\
\mu\left(\lambda, T, c_{\mathrm{e}}\right)=\varepsilon_{\mathrm{w}}\left(\lambda, T, c_{\mathrm{e}}\right) c_{\mathrm{w}}+\varepsilon_{\mathrm{e}}\left(\lambda, T, c_{\mathrm{e}}\right) c_{\mathrm{e}}
\end{gathered}
$$

ここで, $\mu$ は水溶液の吸収係数 $\left[\mathrm{mm}^{-1}\right], c$ はモル濃度 $[\mathrm{M}], \varepsilon$ はモル吸収係数 $\left[\mathrm{mm}^{-1} \mathrm{~mol}^{-1}\right]$ であり, 下添字の $\mathrm{w}$ と e はそれぞれ水と溶質（ここではエタノール）を 表す. Fig. 1 (b)の純水と純エタノールのスペクトルか ら明らかなように, 水の吸収バンドでは $\varepsilon_{\mathrm{w}}>\varepsilon_{\mathrm{e}}$ である ため, $A$ の変化は水分子の体積分率またはエ夕ノール 濃度が支配的な因子となり, 変化量はエ夕ノール固有の 吸収バンド $(\lambda=1700 \mathrm{~nm}$ 付近）のそれよりも大きい. つまり，近赤外域でそれ自体の吸収がほとんどない溶質 や希薄水溶液でも水の吸収バンドを利用することによっ
て測定が可能になる。このとき， $\Delta A$ は $\Delta T$ と $\Delta c_{\mathrm{e}}$ を用 いて次のように表すことができる.

$$
\begin{gathered}
\Delta A(\lambda)=\left[\alpha_{T}(\lambda) \Delta T+\alpha_{c}(\lambda) \Delta c_{\mathrm{e}}\right] d \\
\alpha_{T}(\lambda)=\left(\frac{\partial \mu(\lambda)}{\partial T}\right)_{c_{\mathrm{e}}} \log _{10} e, \\
\alpha_{c}(\lambda)=\left(\frac{\partial \mu(\lambda)}{\partial_{c_{\mathrm{e}}}}\right)_{T} \log _{10} e
\end{gathered}
$$

式(5)は $\Delta A$ が $\Delta T$ と $\Delta c_{\mathrm{e}}$ の線形和で表せることを意味 しており, 係数 $\alpha_{T}, \alpha_{c}$ はある程度限定された温度と濃 度の範囲であれば定数としてよい, 厳密には, 水一溶質 間の相互作用すなわち水和の影響によって， $\mu$ は $c_{\mathrm{e}}$ に 対する非線形的な関数であるため ${ }^{13)}$ ，大きく変動する $c_{\mathrm{e}}$ の正確な定量には注意が必要である。これらの係数 を決定する際には，適切な波長を選択する必要があるが, 先に示した温度変化に対して極大值を取る波長（ $\lambda=$ $1905 \mathrm{~nm})$ と等吸収点 $(\lambda=1935 \mathrm{~nm})$ を利用するのがよ い. 等吸収点を利用する理由は, $\alpha_{T}=0$ より式(5)を 2 波 長で連立して解く際に生じうる共線性を回避でき，かつ 吸収バンドのピーク波長であり $\alpha_{c}$ が最も大きくなるため である．著者らは，常温の $0<c_{i}<0.21 \mathrm{M}$ のエタノール 水溶液において $\lambda=1905 \mathrm{~nm}$ で $\alpha_{T}=0.022 \mathrm{~mm}^{-1} \cdot \mathrm{K}^{-1}$, $\alpha_{c}=-0.443 \mathrm{~mm}^{-1} \cdot \mathrm{M}^{-1}, \lambda=1935 \mathrm{~nm}$ で $\alpha_{c}=-0.378$ $\mathrm{mm}^{-1} \cdot \mathrm{M}^{-1}$ と求めている10).

2 成分以上の水溶液の場合においても特徵的な波長を 見出す必要があるが，スペクトルデー夕に統計分析処理 （ケモメトリックスとも呼ばれる）を用いることも有効 である。これについては 4 節で述べる。

\section{2 イメージング装置}

近赤外吸収イメージングシステムは従来の透過型の吸 光法に基づいて設計できるため, 光学系は比較的単純化 でき，一般の光学顕微鏡と組み合わせることも容易であ る. Fig. 2 にシステムの一例を示す6),10).この例では, 白色光から特定の 2 波長を抽出し, イメージングセンサ

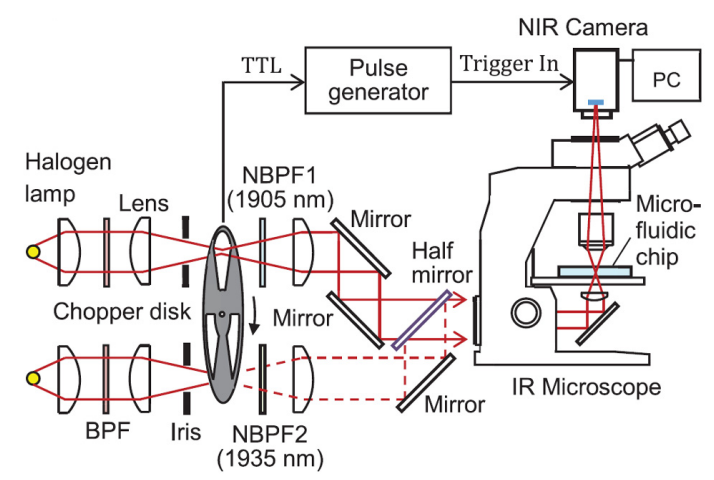

Fig. 2 Illustration of dual-wavelength imaging system. A microfluidic chip was irradiated with two light beams at the wavelengths of $1905 \mathrm{~nm}$ and $1935 \mathrm{~nm}$ alternately by using NBPFs and a rotating chopper disk. The transmitted images are acquired by a NIR camera, synchronized with the timing of irradiation. Reproduced from Ref. 10. 
に一定周期で交互に検出する方法を採用している，具体 的には，2つのハロゲンランプからの光をピーク波長 $1905 \mathrm{~nm}$ と $1935 \mathrm{~nm}$ の狭帯域バンドパスフィルタ （NBPF）を通している.NBPF の半值全幅は小さい方 が望ましいが，10 nm 程度であれば多くの波長で既製品 が存在する。また，NBPF のみでは広带域の光吸収に よる熱ダメージを受けるため, 八ロゲン光源と NBPF の間に $\lambda=1600-2200 \mathrm{~nm}$ のバンドパスフィルタ （BPF）を扦入した．2つの光束はチョッパにより一定 の時間遅れをもって交互に顕微鏡内へと入射され, 試料 の透過光が近赤外カメラに検知される. 近赤外カメラは 感度波長 $1000-2350 \mathrm{~nm}$ の InGaAsII 素子のカメラ （CV-N800，住友電工）を用いた。照射タイミングと同 期するためにチョッパから出力される TTL 信号をもと にパルスジェネレータによってトリガー信号を生成し, カメラに入力している。な扔，波長を増やしたい場合に は, NBPFを取り付けたレボルバを回転させる方法や 光音響素子を用いた方法も採用できる。

\section{3. 拡散現象の可視化と温度依存性}

\section{1 温度・濃度同時イメージング}

近赤外吸収イメージングの一例としてエタノール水溶 液の温度・濃度同時イメージングについて紹介する。用 いたイメージングシステムは Fig. 2 に示したとおりで あり, NBPF の中心波長は $1905 \mathrm{~nm}$ と $1935 \mathrm{~nm}$ である. Fig. 3 に示す Y 字型マイクロ流路に一定流量で水と工 タノール水溶液を流し, 物質拡散による濃度分布を安定 形成させた。このときデイスクヒーターによってチップ 全体が温度制御されており， $T_{\text {set }}=16-44 \mathrm{~K}$ で調整した。

Fig. 4 は $T_{s e t}=16,27 \mathrm{~K}$ のときのエタノール濃度分布 $c_{\mathrm{e}}(x, y)$ と温度分布 $T(x, y)$ である. $T(x, y)$ は流路全域 にわたってほぼ一様となり，これは全体加熱されている ことと水の熱拡散率が比較的大きいためである。一方, $c_{\mathrm{e}}(x, y)$ では水と水溶液の領域が左右で明瞭に区別され るものの, 上流から下流にかけて混合領域が $x$ 方向に広

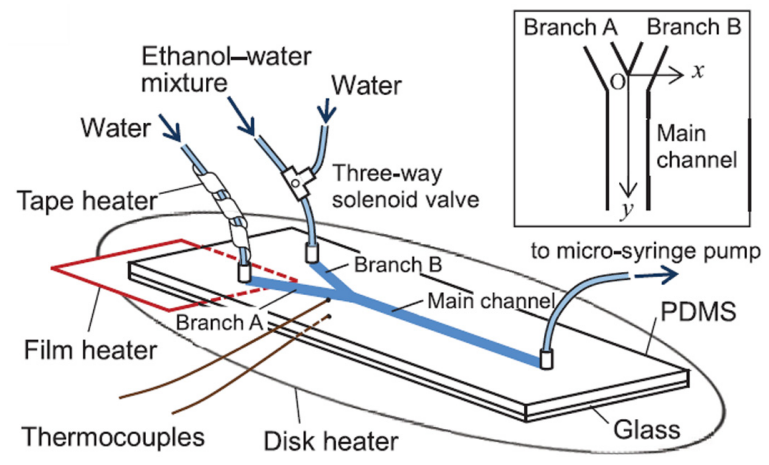

Fig. 3 Schematic showing a PDMS/glass microfluidic chip with a Y-channel. Water flowing in Branch $\mathrm{A}$ was heated by an electrical tape heater and film heater. The temperature of the whole chip was controlled by a disk heater. Reproduced from Ref. 10.

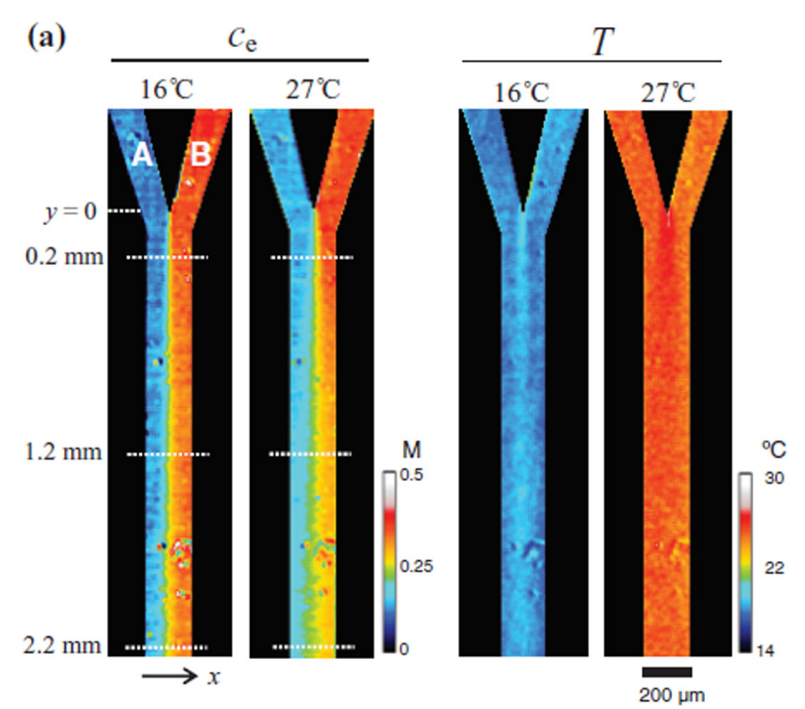

(b)

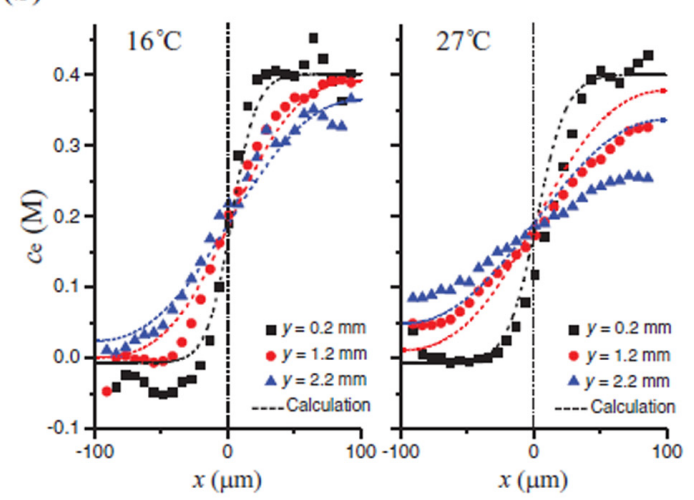

Fig. 4 (a) Images of the ethanol concentration, $c_{\mathrm{e}}$, and the temperature, $T$, at the whole chip temperatures of $16{ }^{\circ} \mathrm{C}$ and $27{ }^{\circ} \mathrm{C}$ when water and ethanol? water mixture with $c_{\mathrm{e}}=0.43 \mathrm{M}(2.0 \mathrm{wt} \%)$ flowed in the main channel through Branch A and Branch B, respectively. (b) Transverse line profiles of $c$ at three positions $(y=0.2,1.2$ and $2.2 \mathrm{~mm})$. For comparison, numerically calculated line profiles are also shown by dashed curves, where the diffusion coefficients of $0.91 \times 10^{-9} \mathrm{~m}^{2} \mathrm{~s}^{-1}$ and $1.30 \times 10^{-9}$ $\mathrm{m}^{2} \mathrm{~s}^{-1}$ for $16{ }^{\circ} \mathrm{C}$ and $27{ }^{\circ} \mathrm{C}$, respectively, were used. Reproduced from Ref. 10.

がっていくことが分かる。また， $T_{s e t}=27 \mathrm{~K}$ の方が広が りも大きく, 拡散が早く進行したことが示されている.

\section{2 拡散係数の温度依存性}

Fig. 4 の $c_{\mathrm{e}}(x, y)$ からは物質拡散係数 $D\left[\mathrm{~m}^{2} / \mathrm{s}\right]$ を算出 することができる。そのために以下に示す移流拡散方程 式(7)をもとに解析解(式 (8))を求めた ${ }^{14)}$.

$$
\begin{gathered}
D \frac{\partial^{2} c_{\mathrm{e}}(x, y)}{\partial x^{2}}-u_{y} \frac{\partial c_{\mathrm{e}}(x, y)}{\partial y}=0 \\
c_{\mathrm{e}}(x, y)=\frac{c_{0}}{2} \operatorname{erfc}\left(\frac{x-x_{0}}{2 \sigma}\right)
\end{gathered}
$$

ただし，

$$
\sigma^{2}=D_{t}=\frac{D}{u_{y}}\left(y-y_{0}\right)
$$


ここで, $u_{y}$ は $y$ 方向の平均流速， $x_{0}$ は流路幅中心の $x$ 座標, $y_{0}$ は合流直後の $y$ 座標である。この算出法は,

一様な $u_{y}$ の押し出し流れにおいて $x$ 方向のみ拡散が生 じるとした仮定に基づいており，初期すなわち合流前の 濃度分布がステップ関数 $\left(c=c_{0}\right.$ for $x \leq x_{0}$; $c=0$ for $\left.x>x_{0}\right)$ のときに得られる式(8) と測定值を フィッティングすることで $D$ を決定する。 マイクロ流 体研究では比較的よく用いられる算出法であるが, 本イ

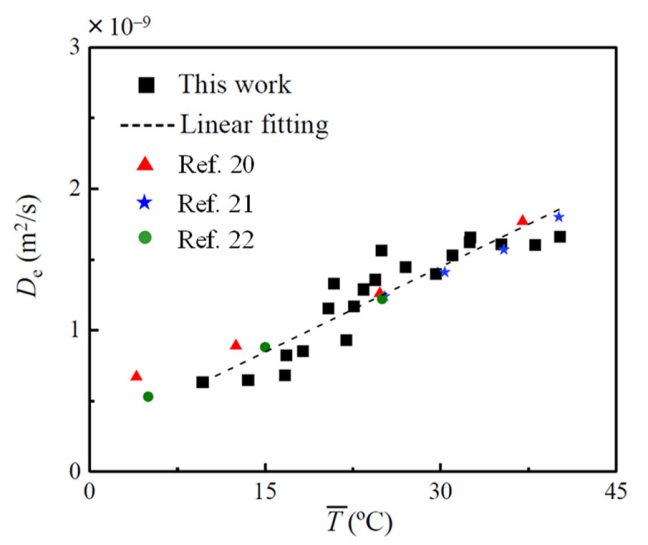

Fig. $5 D$ plots of methanol in water as functions of $T$. The literature values are plotted for comparison. Reproduced from Ref. 16.
メージング法の利点は，2 次元的なフィッティングが可 能であるため信頼性の高い推定ができることと, 同時に 得られる $T$ を参照できることである．こうして得たエ 夕ノール水溶液の $D$ の $T$ に関するプロット ${ }^{16)}$ Fig. 5 に示す. 温度 $T$ が上昇すると線形的に $D$ が上昇するこ とが確認できる．また，他のアルコールや糖についても $D$ と $T$ の関係を求めており ${ }^{16)}$, これらの結果は他の文 献值およびストークス・アインシュタイン式とも矛盾が なく, 計測の妥当性を保証している.

\section{4. 酸・アルカリ中和反応の可視化}

\section{1 近赤外吸収スペクトル}

代表的な化学反応の一つである酸・アルカリ中和反応 の可視化結果を紹介する. Fig. 6 (a)に， $\lambda=1250-1650$ $\mathrm{nm}$ における $\mathrm{HCl}, \mathrm{NaOH}, \mathrm{NaCl}$ 水溶液の吸収スペクト ルを示す。これらの吸収スペクトルの顕著な違いとして, 次の二点があげられる。点目は, $\mathrm{HCl}$ と $\mathrm{NaOH}$ では, $\lambda=1520 \mathrm{~nm}$ において濃度によらない等吸収点が存在す るが, $\mathrm{NaCl}$ では観察されず, $A$ は濃度と共に減少する. この差異は Fig. 6 (b)に示すに $\Delta A$ スペクトルでより明 瞭に確認される。この等吸収点は, $\mathrm{H}^{+}$や $\mathrm{OH}^{-}$の存在に 起因する。 これらのイオンは, $\mathrm{NaCl}$ 同様, 水分子間の 水素結合に影響を与えるが，イオン自体も水分子との水
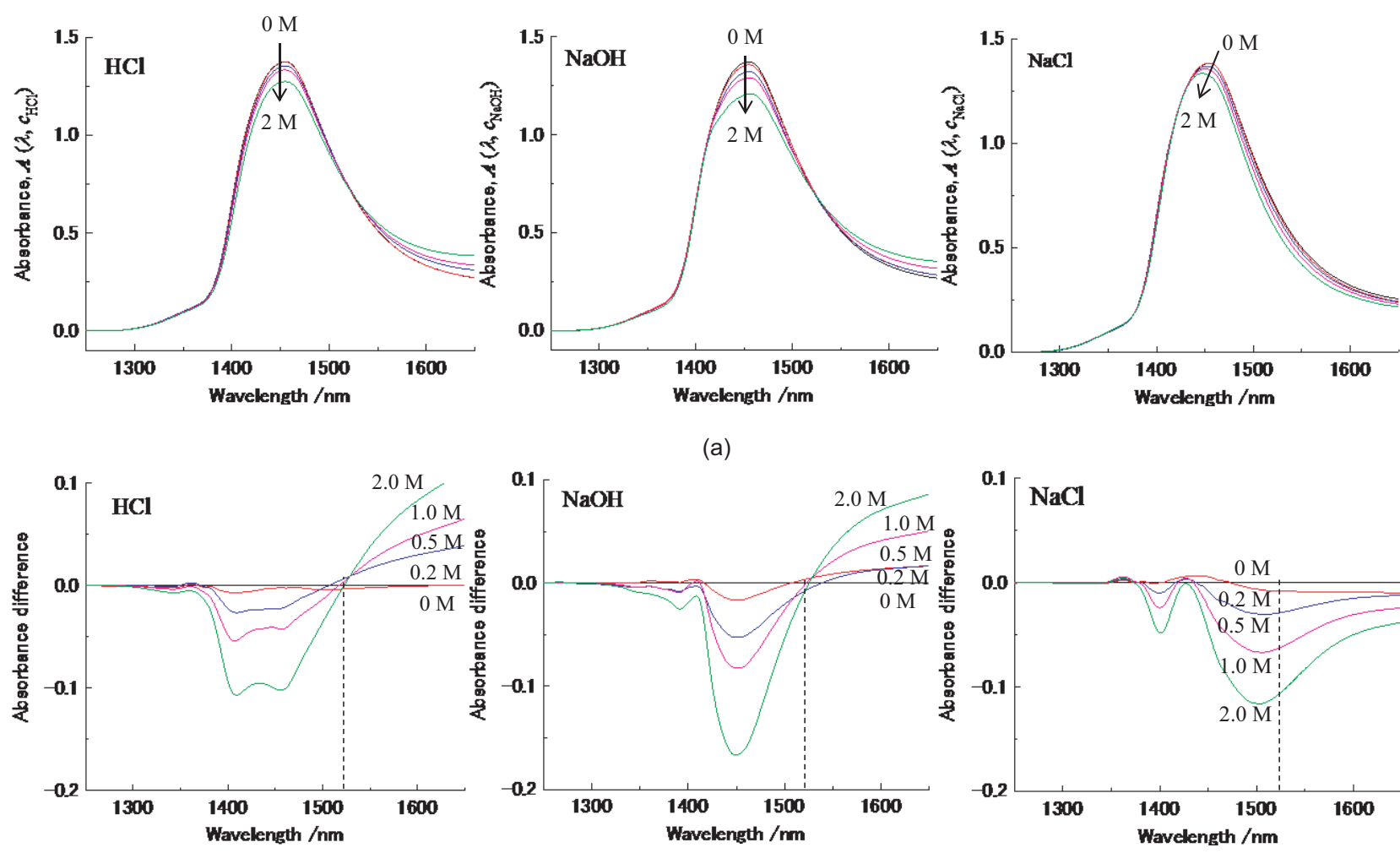

(a)
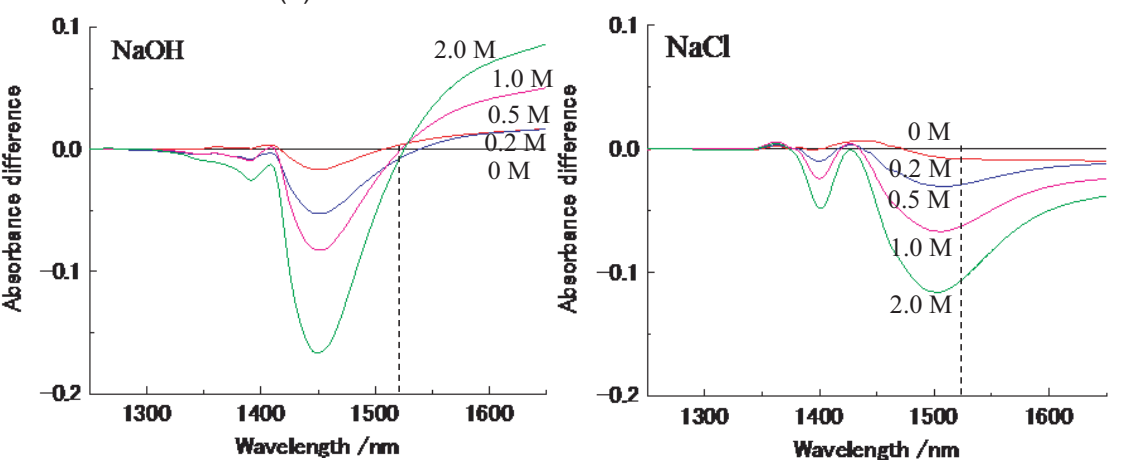

(b)

Fig. 6 (a) Absorbance spectra of aqueous solutions of $\mathrm{HCl}$ (left), $\mathrm{NaOH}$ (center), and $\mathrm{NaCl}$ (right) with the concentrations of $0,0.2,0.5,1.0$, and $2.0 \mathrm{M}$ at the temperature of $20{ }^{\circ} \mathrm{C}$. (b) Absorbance difference spectra of aqueous solutions of $\mathrm{HCl}$ ), $\mathrm{NaOH}$ and $\mathrm{NaCl}$ with the concentrations of $0.2,0.5,1.0$, and $2.0 \mathrm{M}$ at the temperature of $20{ }^{\circ} \mathrm{C}$. The reference is the absorbance of pure water $(0 \mathrm{M})$. The vertical dashed line in each graph indicates the wavelength of $1520 \mathrm{~nm}$. Reproduced from Ref. 17. 
素結合を形成するため, $\mathrm{NaCl}$ とは異なるスペクトル変 化を生じる。二点目は, $\mathrm{HCl}$ と $\mathrm{NaOH}$ では濃度上昇に より $\lambda=1442 \mathrm{~nm}$ のピーク付近の $A$ が全体的に減少す るのに対して, $\mathrm{NaCl}$ では $\boldsymbol{A}$ の減少に加えてピークが短 波長側にシフトすることである，水の吸収バンドは，複 数の水素結合種に帰属されるサブバンドのコンボリュー ションと解釈されており ${ }^{15)}, \mathrm{NaCl}$ で短波長シフトした 原因は, 自由水の割合が水素結合水と比較して相対的に 増加したためと考えられる。

以上の特徵から, 先ず, 等吸収点 $(\lambda=1520 \mathrm{~nm})$ の みを利用することで中和反応時の $\mathrm{NaCl}$ 濃度を計測・イ メージングできることが分かる ${ }^{17)}$. 単一波長計測は害用 性に優れるため，このように等吸収点を見出すことはス ペクトル分析に扔ける基本方針ともいえる. $\mathrm{NaCl}$ と同 時に $\mathrm{HCl}$ と $\mathrm{NaOH}$ を濃度イメージングする場合は, 特 徵的な波長をさらに加えて濃度変換モデルを構築するこ とになるが, 選定波長の妥当性の検証にはステップワイ ズや主成分分析などの統計手法を利用するのがよい.今 回のケースでは， $\lambda=1520 \mathrm{~nm}$ に加えて，1412 nm（HCl のピーク波長でかつ $\mathrm{NaOH}$ ではほとんど変化しない) と $1442 \mathrm{~nm}$ を容易に見出すことができるため, これら 3 波長の重回帰による画像演算により濃度イメージング を行った ${ }^{18)}$. 用いた装置の Fig. 2 と異なる点は, 1 つの ハロゲン光源と， 3 つの NBPFを取り付けた回転レボ ルバを用いた点である。

\section{2 濃度イメージング結果}

Fig. 7 は, $2.0 \mathrm{M}$ の $\mathrm{HCl}$ (流路上側) と $\mathrm{NaOH}(下$ 側）をY 字マイクロ流路に流して合流させたときの各 成分の濃度画像である. Fig.7 (a)，(b)では，流れ方向 ( $x$ 方向) に沿った流路中央付近 $(y \sim 0 \mathrm{~mm})$ に扔いて $\mathrm{HCl}$ と $\mathrm{NaOH}$ が接触し, その界面で両溶液とも濃度が 低くなっていることから，中和反応が生じたことがわか る。 また, Fig. 7 (c) より $\mathrm{NaCl}$ 濃度が接触界面より生 成し, $y$ 方向に拡散している様子が可視化されている.

Fig. 8 は $x=5.7 \mathrm{~mm}$ に扔ける $y$ 方向の濃度プロファ イルである. 中和反応の反応速度定数は $k=10^{9} \mathrm{M}^{-1} \mathrm{~s}^{-1}$ 程度であり ${ }^{199}$ ，速やかに反応を完了することから， $\mathrm{HCl}$

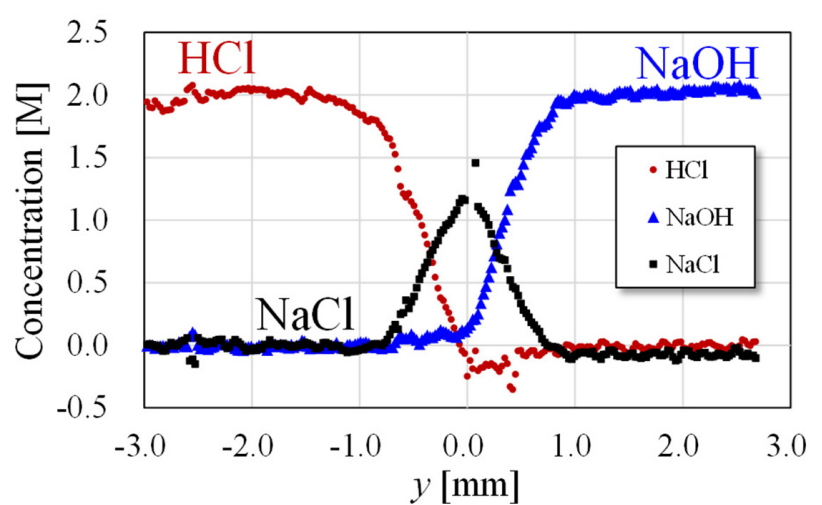

Fig. 8 Concentration profiles of the three solutions along A-A' line shown in Fig. 7. Reproduced from Ref. 18.

と $\mathrm{NaOH}$ の接触と同時に $\mathrm{NaCl}$ が生成し, 反応は拡散律 速として進行していることが示唆されている，言い換え ると, $\mathrm{NaCl}$ の周囲への拡散が生成と鈞り合っており, その領域に供給される $\mathrm{HCl}$ と $\mathrm{NaOH}$ についても相互拡 散により $\mathrm{NaCl}$ と同程度の拡散輸送量となるため, その ような釣り合いが成り立つと考えられる。また，流路中 央の $\mathrm{NaCl}$ 濃度は, 設定された $\mathrm{HCl}$ と $\mathrm{NaOH}$ 濃度のお よそ半値を示した。これは化学量論的に生成塩のモル数 は反応物のそれと等しいが，体積が 2 倍になるためであ る.このとき同時に $\mathrm{H}_{2} \mathrm{O}$ も生成するが, 溶媒としての 水が元々多量に存在するため, 水の体積分率変化はおよ そ $2 \%$ とさく, 濃度への影響はほとんどない.

\section{5. おわりに}

本稿では, 近赤外吸収イメージング法の基礎原理と装 置を解説し, 可視化および解析結果の一例を紹介した。 近赤外域に現れる水の吸収スペクトルは溶質種や温度ご とにユニークなものであるため, 本稿で紹介した以外の 水溶液や反応系にも本方法は応用可能である。 そのため のスペクトルデータと濃度変換モデルの提供が著者らの 今後の課題のひとつと考えている. 本方法はシンプルな 光学系および画像処理系が特長であるが, 普及にはハー ドウェアの低価格化と使いやすさが求められる. 分光照 射光源については, 音響光学式フィルタや液晶型フィル

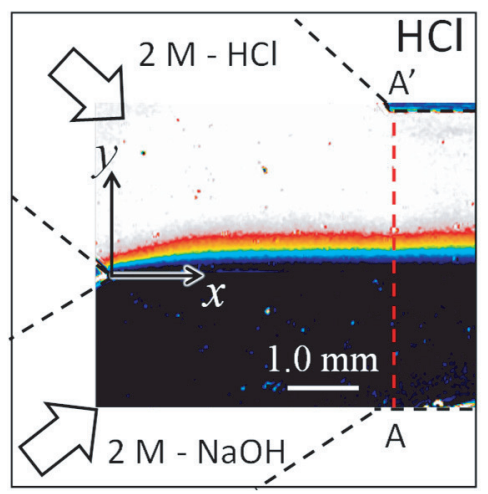

(a) $\mathrm{HCl}$

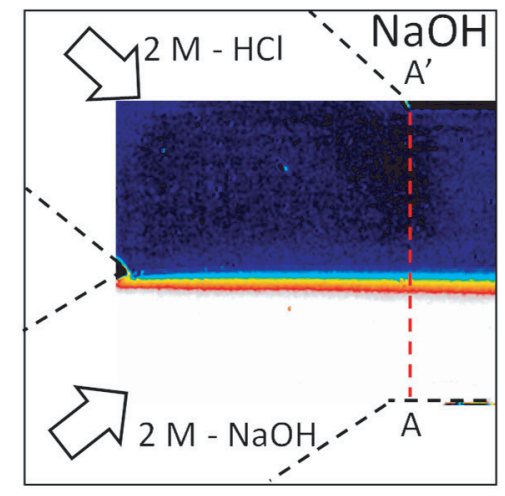

(b) $\mathrm{NaOH}$

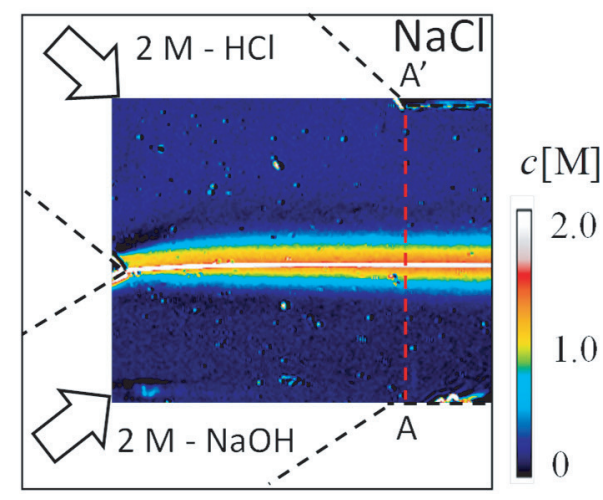

(c) $\mathrm{NaCl}$

Fig. 7 Concentration images of (a) $\mathrm{HCl}$, (b) $\mathrm{NaOH}$, and (c) $\mathrm{NaCl}$. Reproduced from Ref. 18. 
夕などの任意波長を選択できるデバイスが今後入手しや すくなるかもしれない. 近赤外カメラについては, 現状, 波長 900-1700 nm に感度を有する InGaAs カメラは比 較的低価格で機種も多い. 一方, 波長 $1900 \mathrm{~nm}$ 帯をカ バーする感光素子は未だ高価であるが，一般的なマイク ロ流路深さである 0.01-0.1 mm の測定に適しているこ とを考えると, 将来的に主要な分析波長帯になる可能性 がある．また，可視域のようなハイスピードで撮像でき る近赤外カメラも今後期待され，その辺りの環境が整え ば，本方法による可視化の対象がさらに広がっていくと 期待する。

\section{謝 辞}

本研究を進めるにあたりご指導を頂きました電気通信 大学の山田幸生先生に深く感謝を申し上げます。また， 実験, 解析に協力頂きました山下大樹氏, 大畑俊哉氏に 感謝申し上げます。

\section{参 考文 献}

1 ) Elvira, K. S., Solvas, X. C., Wootton, R. C. R., A. J. deMello : The past, present and potential for microfluidic reactor technology in chemical synthesis, Nat. Chem., Vol.5 (2013) pp.905-915.

2 ) Jensen, K. F., Reizman, B. J., Newman, S. G., Tools for chemical synthesis in microsystems, Lab Chip, Vol.14 (2014) pp.3206-3212.

3 ) Hoffmann, M., Schlüter, M., Räbiger, N. : Experimental investigation of liquid-liquid mixing in T-shaped micro-mixers using LIF and PIV, Chem. Eng Sci., Vol.61 (2006) pp. 2968-2976.

4) Kuriyama, R., Sato, Y. : An investigation of measurement condition for non-intrusive velocity determination based on thermal tracing by Raman imaging, J. Therm. Sci. Tech.-Jpn., Vol.9, Issue 2 (2014), p.JTST0014.

5 ) Liu, X., Zhao, T., Obara, H., Cui, Y., Takei, M. : Image reconstruction under contact impedance effect in micro electrical impedance tomography sensors, IEEE Trans. Biomed. Circuits Syst., Vol.12, 3 (2018), pp.623-631.

6 ) Kakuta, N., Fukuhara, Y., Kondo, K., Arimoto, H., Yamada, Y. : Temperature imaging of water in a microchannel using thermal sensitivity of near-infrared absorption, Lab Chip, Vol.11 (2011), pp.3479-3486.

7 ) Kakuta, N., Nishijima, K., Kondo, K. Yamada, Y. : Nearinfrared measurement of water temperature near a 1-mmdiameter magnetic sphere and its heat generation rate under induction heating, J. Appl. Phys., Vol.121 (2017) 044901.

8 ) 角田直人, 近藤克哉, 有本英伸, 山田幸生 : 水の近赤外吸収
特性を利用した非接触温度イメージング，システム制御情報 学会誌, Vol.57, No.12 (2013), pp.493-498.

9 ) Manley, M. : Near-infrared spectroscopy and hyperspectral imaging: Non-destructive analysis of biological materials, Chem. Soc. Rev., Vol.43, Issue 24 (2014) pp. 8200-8214.

10) Kakuta, N., Yamashita, H., Kawashima, D., Kondo, K., Arimoto, H., Yamada, Y. : Simultaneous imaging of temperature and concentration of ethanol-water mixtures in microchannel using near-infrared dual-wavelength absorption technique, Meas. Sci. Technol., Vol.27 (2016) 115401.

11) Libnau, F.O., Kvalheim, O.M., Christy, A.A., Toft, J : Spectra of water in the near-and mid-infrared region, Vib. Spectrosc., Vol.7, Issue 3 (1994) pp.243-254.

12) Segtnan, V. H., Šašić, Š., Isaksson, T., Ozaki, Y. : Studies on the structure of water using two-dimensional near-infrared correlation spectroscopy and principal component analysis, Anal. Chem., Vol.73, No.13 (2001) pp.3153-3161.

13) Onori, G., Santucci, A. : Dynamical and structural properties of water/alcohol mixtures, J. Mol. Liq., Vol.69 (1996) pp. 161-181.

14) Kirby, B. J. : Micro-and Nanoscale Fluid Mechanics, Cambridge University Press (2010).

15) Šašić, Š., Segtnan, V. H., Ozaki, Y. : Self-modeling curve resolution study of temperature-dependent near-infrared spectra of water and the investigation of water structure, J. Phys. Chem. A, Vol.106, No.5 (2002) pp.760-766.

16) Yamashita, H., Kakuta, N., Kawashima, D. Yamada, Y., Measurement of temperature-dependent diffusion coefficients of aqueous solutions by near-infrared simultaneous imaging of temperature and concentration, Biomed. Phys. Eng. Express, Vol.4, No.3 (2018), p.035030.

17）川嶋大介, 角田直人, 有本英伸, 近藤克哉, 山田幸生, 近赤 外域の単一波長を利用した中和反応で生成する塩濃度の可視 化，可視化情報学会論文集，Vol.36, No.12 (2016) pp.62-70.

18）大畑俊哉, 角田直人, 川嶋大介, 山田幸生, マイクロ流路内 の中和反応に扔ける反応・生成物の濃度イメージング，第 45 回可視化情報シンポジウム (2017.7), F103.

19) Buxton, G. V., Greenstock, C. L., Helman, W. P., Ross, A. B. : Critical review of rate constants for reactions of hydrated electrons, hydrogen atoms and hydroxyl radicals (OH/O-) in aqueous solution, J. Phys. Chem. Ref. Data, Vol.17, No.2 (1988), pp.513-886.

20) Gary-Bobo, C. Weber, H. W. : Diffusion of alcohols and amides in water from 4 to $37^{\circ}$, J. Phys. Chem., Vol.73, Issue 4 (1969) pp. $1155-1156$.

21) Pratt, K. C., Wakeham, A. : The mutual diffusion coefficient of ethanol-water mixtures: determination_by a rapid, new method, Proc. Royal Soc. A, Vol.336, Issue 1606 (1974) pp.393-406.

22) Easteal, A. J., Woolf, L. A., Pressure and temperature dependence of tracer diffusion coefficients of methanol, ethanol, acetonitrile, and formamide in water, J. Phys. Chem. Vol.89, No.7 (1985) pp.1066-1069. 